\title{
Türkiye'de Yüksek Öğretim Harcamaları ve Genç İşsizliği İlişkisi Üzerine Bir Analiz
}

\author{
An Analysis of the Relationship between Higher Education Expenditures \\ and Youth Unemployment in Turkey
}

\section{Muammer MARAL ${ }^{1} \odot$, Furkan YILDIZ $^{2} \oplus$, Yusuf ALPAYDIN ${ }^{3} \odot$}

\section{öz}

İşsizlik ve özellikle genç işsizlik problemi birçok bilimsel araştırmaya konu olmuş bir alandır. Genç işsizliğinin temel nedenleri ve olası çözüm yolları üzerinde bilim insanları uzun süre çalışmış ve halen çalışmaya devam etmektedir. Ancak genç işsizlik, birçok faktörden etkilenen oldukça karmaşık ve küresel bir sorundur. Dünyada giderek artan genç işsizliğin temel nedenleri, sonuçları, olası çözüm yolları üzerine farklı bilim disiplinleri farklı bakış açıları ile eğilmiş, çeşitli görüş ve öneriler ortaya atılmıştır. Bu çalışmanın temel amacı 1988-2019 dönemi için Türkiye'de var olan genç işsizliğini belirleyen faktörleri analiz etmektir. Çalışmanın bağımlı değişkeni genç işsizliği olup bağımlı değişken üzerinde etkisinin test edildiği temel değişken yüksek öğretim harcamalarıdır. Çalışmada kullanılan diğer kontrol değişkenler ise sırasıyla kişi başına düşen reel gayri safi yurtiçi hasıla, brüt sermaye oluşumu ve emek verimliliğidir. Çalışmada seriler arasında kısa ve uzun dönemli bir ilişki olup olmadığını test eden ARDL eş bütünleşme yaklaşımı kullanılmıştır. Analiz sonuçlarından elde edilen bulgular genç işsizliğinin; yükseköğretim harcamaları ve brüt sermaye oluşumu ile negatif, kişi başına düşen reel gayri safi yurtiçi hasıla ve emek verimliliği ile pozitif ilişkili olduğunu göstermektedir. Uzun dönem katsayıları karşılaştıııldığında genç işsizlik üzerinde en yüksek etkiye sahip olan bağımsız değişken kişi başına düşen GSYH olup bu değişkeni sırasıyla brüt sermaye oluşumu, yüksek öğretim harcamaları ve emek verimliliği takip etmektedir.

Anahtar Kelimeler: Yükseköğretim harcamaları, Genç işsizlik, Brüt sermaye oluşumu, Türkiye, Zaman serisi

Jel Sınıflaması: E24,J20, J580

DOI: 10.26650/JEPR.907984

'Marmara Üniversitesi, Eğitim Bilimleri Enstitüsü, Eğitim Bilimleri Bölümü, İstanbul, Türkiye

${ }^{2}$ Kırklareli Üniversitesi, İktisadi ve İdari Bilimler Fakültesi, Iktisat Bölümü, Kırklareli, Türkiye

${ }^{3}$ Marmara Üniversitesi, Atatürk Eğitim Fakültesi, Eğitim Bilimleri Bölümü, İstanbul, Türkiye

ORCID: M.M. 0000-0002-2055-5711;

F.Y. 0000-0002-1822-1341;

Y.A. 0000-0001-8263-8793

\section{Sorumlu yazar/Corresponding author:}

Furkan YILDIZ,

Kırklareli Üniversitesi, Íktisadi ve İdari Bilimler Fakültesi, İktisat Bölümü, Kırklareli, Türkiye

E-posta/E-mail: furkan.yildiz@klu.edu.tr

Başvuru/Submitted: 01.04 .2021

Revizyon Talebi/Revision Requested: 25.05.2021

Son Revizyon/Last Revision Received: 29.05.2021

Kabul/Accepted: 31.05 .2021

Atıf/Citation: Maral, M., Yildiz, F., Alpaydin, Y. (2021). Türkiye'de yüksek öğretim harcamaları ve genç işsizliği ilişkisi üzerine bir analiz. iktisat Politikası Araștırmaları Dergisi - Journal of Economic Policy Researches, 8(2), 173-197. https://doi.org/10.26650/JEPR.907984 


\section{ABSTRACT}

The problem of unemployment-especially among youth—has been the subject of many scientific studies. Scientists have worked on the main causes of youth unemployment and possible solutions for a long time and are still working on it. However, youth unemployment is a complex, global problem that is affected by many factors. Various scientific disciplines have dealt with different perspectives on the main causes, consequences and possible solutions of youth unemployment. The problem is increasing worldwide, and various opinions and suggestions have been put forward. The main objective of this study is to analyze the determinants of youth unemployment in Turkey for the period 19882019. The dependent variable of the study is youth unemployment, and the main variable that affects the dependent variable is higher education expenditures.

Other control variables used in the study are real gross domestic product per capita, gross capital formation and labor productivity, respectively. The Autoregressive Distributed Lag Bounds Testing (ARDL Test) approach, which tests whether there is a short and long-run relationship between the series, was used in the study. The findings obtained from the analysis results indicate that youth unemployment is negatively associated with higher education expenditures and gross capital formation. It is positively associated with real gross domestic product per capita and labor productivity. When the long-term coefficients are compared, the independent variable that has the highest impact on youth unemployment is gross domestic product per capita, followed by gross capital formation, higher education expenditures and labor productivity, respectively.

Keywords: Higher education expenditures, Youth unemployment, Gross capital formation, Turkey, Time series Jel Classification: E24, J20, J580

\section{EXTENDED ABSTRACT}

Unemployment is a serious global problem. The problem of youth unemployment in particular has been the subject of many scientific studies, and the main causes and possible solutions to this problem have been evaluated and various solutions have been put forward. However, youth unemployment is a complex problem with no single solution. It is affected by many different factors. Moreover, the youth unemployment problem is getting bigger day by day. According to the statistics of the International Labor Organization (2020), the young population (15-24 years of age) increased from 1 billion to 1.3 billion between 1999-2019, but the number of young people participating in employment decreased from 568 million to 497 million. Many studies in different disciplines have been conducted on the main causes, results and possible solutions of the increasing youth unemployment problem. All these studies approach youth unemployment from different angles and offer different solutions to the problem. A complex problem such as youth unemployment is affected by many different factors.

This study examines the effects of the variables of real gross domestic product per capita, labor productivity, gross capital formation, and higher education expenditures on youth unemployment — all of which are thought to affect youth unemployment. The study aims to make suggestions about youth unemployment by revealing the effects of these variables on youth unemployment. The study is based on quantitative data analysis and, in particular, time series analysis has been applied. The dataset used in the study was created based on the relevant literature and used the longest possible time interval. In addition, this study differs 
from the limited number of previous studies in terms of the countries, datasets, and econometric methods used.

The data set used in the study was composed of annual observations that covered the period 1988-2019. The dependent variable of the study is youth unemployment. Independent variables tested for their long-term relationships with youth unemployment are higher education expenditures, real gross domestic product per capita at constant prices in 2010 (\$), gross capital formation at constant prices (\$) in 2010, and labor productivity.

An autoregressive distributed lag bound test (ARDL test) was used to analyze the data. Unlike Engle and Granger (1987) and Johansen (1988) cointegration tests, this test analyzes whether there is a long-term relationship between the series, regardless of whether the series is stationary at the level or at the first difference. However, this method obtains consistent results even in data with small number of observations (Baek \& Kim, 2013; Panopoulou \& Pittis, 2004) and a simultaneous estimation of short- and long-term results. First of all, the stationarities of the variables of the study were tested by Augmented Dickey-Fuller and Phillips-Perron unit root tests. According to this, the young unemployment dependent variable is stationary at the $1 \%$ significance level in the first difference under both unit root tests, and the gross domestic product and gross capital formation independent variables are stationary at the first difference and 1\% significance according to the Augmented DickeyFuller and Phillips-Perron tests. Higher education expenditures and labor productivity independent variables are stationary at the $1 \%$ significance level. Then, using the Akaike Information Criterion (AIC), the lag lengths of the variables of the model were determined and, with the F test, the existence of a long-term relationship between youth unemployment, higher education expenditures, real gross domestic product per capita, gross capital formation, and labor productivity. The ARDL test was applied in the next step.

The results of the study are as follows: (1) There is a long-term relationship at a $1 \%$ significance level between youth unemployment, higher education expenditures, real gross domestic product per capita, gross capital formation and labor productivity. (2) When the long-term coefficients are compared, the independent variable that has the highest impact on youth unemployment is real gross domestic product per capita, followed by gross capital formation, higher education expenditures and labor productivity, respectively. (3) It has been observed that a $1 \%$ increase in higher education expenditures decreases youth unemployment by $0.058 \%$. (4) A $1 \%$ increase in real gross domestic product per capita increases youth unemployment by $2.654 \%$. (5) Gross capital formation has a negative and statistically significant effect at a $5 \%$ level on youth unemployment, and a $1 \%$ increase in gross capital formation reduces youth unemployment by $1.183 \%$. (6) It has been determined that there is a statistically positive relationship between labor productivity and youth unemployment at a $1 \%$ significance level. It has been calculated that a $1 \%$ increase in labor productivity in the long run increases youth unemployment by $0.01 \%$. 


\section{Giriş}

İşsizlik, tüm dünyada küresel sorunlar arasında yerini almış ve birçok ülke için ciddi boyutlara ulaşmış bir sorundur. İşsizlik ve özellikle genç işsizlik sorunu birçok bilimsel araştırmaya konu olmuş, bu sorunun temel nedenleri ve olası çözümleri üzerinde tartışılmış ve çeşitli fikirler ortaya atılmıştır. Ancak genç işsizlik sorunu, tek çözümü olmayan, çok farklı faktörlerden etkilenen oldukça karmaşık bir sorundur. Öyle ki, genç işsizlik sorunu, gün geçtikçe daha da büyümektedir. Uluslararası Çalışma Örgütü'ne (ILO) (2020) göre genç nüfus (15-24 yaş), 1999-2019 yılları arasında 1 milyardan 1,3 milyara yükselmiş ancak istihdama katılan genç sayısı 568 milyondan 497 milyona düşmüştür. ILO’ya göre bu eğilim, ortaöğretim ya da yükseköğretime olan kayıt artışını ve birçok ülkede daha nitelikli işgücünü yansitırken, aynı zamanda istihdamda, eğitim-öğretimde yer almayan ve büyük çoğunluğunu kadınların oluşturduğu genç insanları ifade etmektedir. Küresel genç işsizlik oranı \%13,6 iken, Kuzey Afrika’da bu oran \%30’a kadar çıkmaktadır. Tüm bunların yanında gençlerin işsiz kalma olasılığı 25 yaş ve üzeri yetişkinlerin işsiz kalma ihtimalinden 3 kat daha fazladır.

Genç işsizliğinin bireylerin ve toplumun gelişmesine önemli olumsuz etkileri bulunmaktadır. Genç işsizliğinin bu olumsuz etkileri ülke ekonomisinin zarar görmesinden, suç oranlarının artmasına kadar geniş bir yelpazeyi kapsamaktadır. Ülkeler genç işsizliğin olumsuz etkilerinden korunmak, toplumun ve ülkenin gelişmişliğini sağlamak için bu küresel sorun karşısında çeşitli politikalar planlayarak ve uygulayarak genç işsizliğin üstesinden gelme çabasındadır. Ancak, uygulanan politikalar bazı ülkelerde olumlu sonuçlar doğururken bazı ülkelerde genç işsizliğin azalmasına bir etki etmemektedir.

Giderek artan genç işsizlik probleminin temel nedenleri, sonuçları, olası çözüm yolları üzerine değişik disiplinlerde birçok çalışma yapılmıştır. Yapılan tüm bu çalışmalar genç işsizliğe farklı açılardan yaklaşmakta ve soruna farklı çözüm önerileri sunmaktadır. Bunun en temel sebebi, genç işsizlik gibi karmaşık bir sorunun çok farklı faktörlerden etkilendiği düşüncesidir. Bu çalışmada genç işsizliği etkilediği düşünülen gayri safi yurt içi hasıla (GSYH), emek verimliliği, brüt sermaye oluşumu, yükseköğretim harcamaları değişkenlerinin genç işsizlik üzerindeki etkilerinin incelenmesi amaçlanmıştır. Çalışmada, söz konusu değişkenlerin genç işsizlik üzerindeki etkilerini ortaya koyarak genç işsizliğe ilişkin önerilerde bulunulması hedeflenmiştir. Çalışma nicel veri analizine dayanmaktadır ve özelde zaman serileri analizi uygulanmıştır. Çalışmada kullanılan veri seti ilgili literatüre dayanarak mümkün olan en uzun zaman aralığı kullanılacak biçimde oluşturulmuştur. Ayrıca bu çalışma ele alınan ülke, veri seti ve kullanılan ekonometrik yöntem bakımından daha önce yapılmış sınırlı sayıda çalışmadan ayrılmaktadır.

\section{Kavramsal Çerçeve}

ILO’ya göre işsizlik; çalışma çağında bulunan, referans dönem boyunca çalışmayan (ücretli veya serbest meslek sahibi olmayan) bütün bireyleri, şu anda işe hazır olanları, iş 
arayanları (belirli bir dönemde ücretli iş veya serbest meslek için girişimde bulunmak) kapsamaktadır. Uluslararası karşılaştırma yapabilmek amacıyla iş arama dönemi genel olarak önceki dört haftayı kapsamaktadır. Ancak bu ülkeden ülkeye değişim göstermektedir (ILO, 2019). Genç işsizlik ise çalışma isteği ve gücüne sahip olan, iş aradığ arzusu dışında iş bulamamış 15-24 yaş aralığındaki bireyleri kapsamaktadır (Kelleci \& Türk, 2016).

Literatürde genç işsizliğe ilişkin farklı bakış açıları mevcuttur. Konjonktürel yaklaşıma göre genç işsizliğinin sebebi, uygun tipte işlerin eksik olmasından kaynaklanmaktadır (Çetinkaya, 2010). Yapısal yaklaşım ise genellikle işlerin gençlerin sahip olmadığı becerilere veya diğer bazı özelliklere sahip bireyleri artan bir şekilde talep ettiğini ve gençlerin bu duruma uyum sağlayamadıklarını iddia etmektedir. Bu nedenle yapısal yaklaşım mevcut işsizlik oranını tümüyle ya da büyük oranda durgunluğa bağlı olduğu görüşüne karşı çıkmaktadır. (Raffe, 1986).

İş ve istihdam, bireylerin bireysel ve sosyal kimliklerini biçimlendiren; yaşamlarını, gelirlerini, öz saygısını, sosyo-ekonomik statülerini ve politik konumlarını düzenlemeleri için oldukça önemli bir etkendir (Calderon, 2004). Gençler arasında işsizliğin yüksek olmasının nedenlerini ortaya koymak, diğer yaş gruplarına göre daha zor ve karmaşıktır (Watcher, 1980; aktaran: Çetinkaya, 2010).

Literatürde genç işsizliğin nedenlerine ilişkin birçok görüş ortaya atılmıştır. Genç işşizlik birçok faktörden etkilenmektedir. Genel olarak genç işsizliği etkileyen faktörler makro ve mikro nedenler olarak iki sınıfa ayrılmaktadır. Makro nedenler olarak; talebin yetersiz olması, ekonmik krizler, ülkenin demografik yapısı, eğitim sisteminin nitelikli işgücünü sunamaması, istihdamda ücret politikaları ve asgari ücret uygulamaları sayılabilir. Mikro nedenler ise gençlerin günümüzde eğitimlerine devam etmek istemesi; eğitimli işsizlerin ortaya çıkması; gençlerin işten ayrılmaya ve daha sık iş değiştirmeye yatkın olması; işverenlerin yetişmiş işgücü talebinden dolayı gençlerin işe alımlarına olumsuz bakmaları, gençlerin ilk defa bir işe girecek olması, gençlerin işe alımlarının yetişkinlere göre daha masraflı olması, bireylerin etnik kökeni ve engellilik durumlarıdır (Murat \& Şahin, 2011; O’Higgins, 1997). Breen (2005) tarafından yapılan araştırmada OECD ülkeleri arasındaki genç işsizliğe yönelik farklılıkların nedeni kurumsal ve ekonomik bağlamda incelenmiş, yetişkin işsizlik düzeyine göre genç işsizliğinin işverenlerin uygun olmayan işçileri işten çıkarma özgürlüklerinin sınırlandırıldığı düzenlenmiş işgücü piyasalarında yüksek olduğunu, aksine liberal işgücü piyasalarında ve ayrıca eğitim sisteminin iş arayanların yetenekleri ve becerileri göz önüne alındığı ülkelerde ise düşük olma eğiliminde olduğu belirlenmiştir.

Genç işsizliğin belirtilen birçok nedeni belirli sonuçları da beraberinde getirmektedir. Genel olarak genç işsizlik; ekonomik, sosyal ve psikolojik sonuçlar doğurmaktadır. 
Gençlerin üretime katılamamaları, üretimde eksik ya da kayıp istihdamın orataya çıkması, vergilerin azalması, kayıt dışı istihdamın artması, bireysel gelirin azalması ve gelir dağılımının bozulması, devlet giderlerinde artış olması, tasarrufların azalması, gençlerin eğitimleri için ayrılan kaynakların israf olması genç işsizliğin ekonomik sonuçlarındandır. Genç işsizliğin sosyal sonuçları ise ekonomik sonuçları gibi çeşitlilik göstermektedir. İşsiz gençlerin sisteme kızgın olmaları, suç işleme oranlarının artması, politik olarak bireylerin marjinalleşmesi, gençlerin sosyal dışlanmaları, zararlı alışkanlıkların artması, bireylerin uzun süre işsiz kalma nedeniyle çok düşük ücretli işlerde çalışmaları gibi etkenler genç işsizliğin sosyal sonuçları arasında sayılabilir (Murat \& Şahin, 2011; Özer \& Topal, 2017; Pirler, 2007; Sapancalı, 2005; Seçer, 2006; Yılmaz, Fidan \& Karataş, 2004). Yapılan araştırmada, istihdam yaşam dönügüsünde erken dönemlerde yaşanan işsizliğin kazanç üzerinde uzun dönemli olumsuz etkileri olduğu, genç işsizliğin bireylerin yakın gelecekte eğitim alma ihtimalini artırdığı gençlerin yaşadığı işsizlikten sonra sürekli olarak aralıklı, düşük ücretli işlerde çalıştığını düşüncesi yerine gençlerin eğitim ve çalışma faaliyetini içinde oldukları sonucuna ulaşmıştır (Mroz \& Savage, 2006). Genç işsizliğin psikolojik sonuçları arasında ise stres, özgüven kaybı, psikolojik sağlık problemleri, yaşam tatmininin azalması, intihar oranlarının artması sayılabilir.

Şekil 1. Genç İşsizlik Oranları (15-24 yaş, 2019 yılı) (\%)

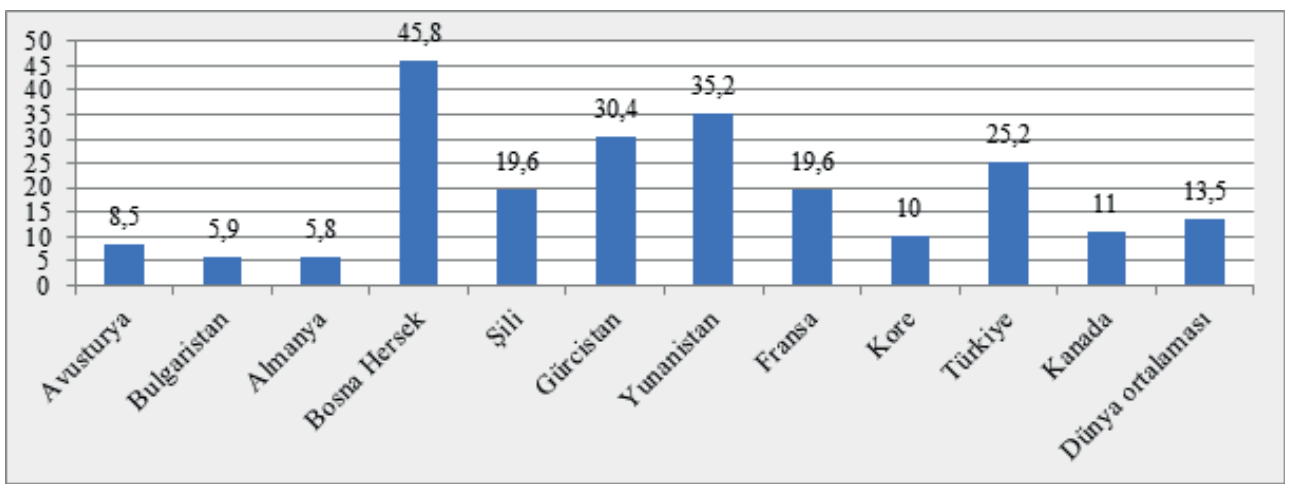

Kaynak: (ILO, 2019)

Şekil-1'de bazı ülkelerde genç işsizlik oranları verilmiştir.Şekil-1'de görüldüğü gibi genç işsizlik gelişmiş ülkelerde bile sorun olarak ortada durmaktadır. Dünya' da genç işsizlik oranı \%13 seviyesindedir. Türkiye'de ise 2019 yılı verilerine göre genç işsizlik \%25,2'dir. Bazı ülkelerde ise genç işsizlik seviyeleri çok daha ciddi boyutlara ulaşmıştır. Sunulan tablo genç işsizliğin küresel bir problem olduğunun önemli göstergelerinden biridir. 
Şekil 2. Türkiye'de Yıllara Göre Genç İşsizlik Oranları (\%)

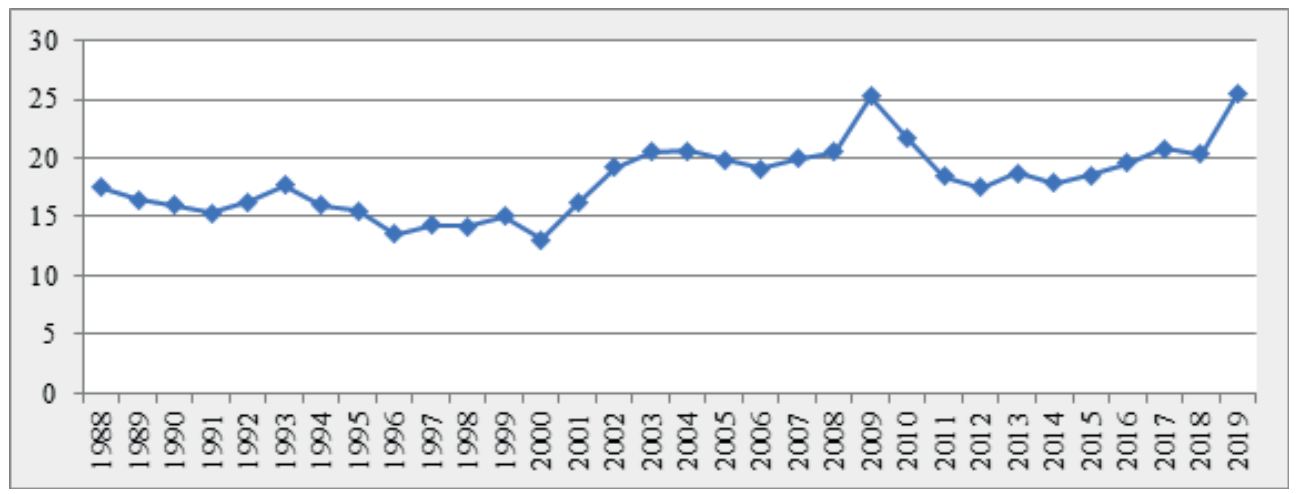

Kaynak: (TÜIK, 2021)

Şekil-2’de 1988 yılında 2019 yılına kadar olan süreçte Türkiye'de genç işsizlik oranları verilmiştir. Buna göre Türkiye'de genç işsizliğinin dalgalı bir seyir gösterdiği, istikrarlı olarak artıp azalmadığı görülmektedir. Ancak genel olarak bakılacak olursa 1988 yılından 2000 yılına kadar olan süreçte genç işsizlik oranları azalış göstermiş, 2001 yılından 2019 yılına kadar dalgalı da olsa çıkış eğilimi sergilenmiştir. 1988 yılında \%17,5 olan genç işsizlik oranı, 2000 yılında \%13,1'e düşmüş, ancak 2019 yılında \%25,4'e yükselerek 32 yıllık süreçte en üst seviyeyi görmüştür.

Türkiye'de genç işsizliğin yüksek olmasının bazı sebepleri bulunmaktadır. Nitelik bakımından iş gücü talebi ile arzı arasındaki uyuşmazlık, meslek liselerine yoğun talep olmasına karşın meslek liselerinin istenilen nitelikte ve kalitede eğitim verememesi (Gürsel, 2005: Akt; Apaydın, 2018), gençlerin ilk işe girdiklerinde aldıkları ücretleri beğenmemesi ve işten ayrılmalarının daha kolay olması (Seçer, 2006), genç işsizliğin yüksek olması ve gençlerin eğitim hayatlarına devam etmelerini istemeleri (Kavak, 1997), işsizliğin bir süre sonra kabullenilmesi, iş arama yollarının gençler tarafından yanlış seçimi (Apaydın, 2018), ekonominin yapısal sorunları, sanayileşme politikaları, gençler tarafından yanlış yöntemlerle iş aranması (İzgi, 2012) bu nedenler arasındadır.

\section{Literatür}

Literatürde işsizlik/genç işsizliğe neden olan faktörleri belirlemek için birçok çalışma yapılmıştır. Bu çalışmalar; kullanılan yöntem, incelenen veri seti, dönem, ele alınan ülke/ ülke grubundaki farklılıklar nedeniyle birbiri ile örtüşmeyen sonuçlar ortaya koymaktadır. Aşağıda ilgili literatür bu çalışmada kullanılan göstergeler bağlamında kategorize edilerek verilmiştir. Böylelikle bu başlık altında hem ilgili literatür hem de bu çalışmada kullanılan değişkenlerin tercih edilme nedenleri açıklanmıştır. 


\subsection{Ekonomik Büyüme (GSYH) ve Genç İşsizlik}

Ekonomik büyüme, bir ülkenin ulusal gelirinde kalıcı artış olarak tanımlanmaktadır (Hesapçığlu, 1984). Diğer bir ifade ile ekonomik büyüme, toplumun ihtiyaçlarına yönelik mal ve hizmetlerin üretim kapasitesindeki artış, kişi başına düşen üretimdeki artıştır. Kısacası ekonomik büyüme, milli gelirdeki artış ifade etmektedir (Gümüş \& Şişman, 2014). Ekonomik büyüme ile işsizlik arasında negatif, istihdam arasında ise pozitif bir ilişkinin varlığ 1 beklenir. Diğer bir deyişle, ekonomik büyüme meydana geldikçe işsizliğin azalması, ancak istihdamın artması beklenir (Murat \& Yılmaz Eser, 2013). Bu durum iktisat literatüründe Okun Yasası olarak adlandırılmıştır. Okun Yasası'na göre ekonominin büyümesi istihdam oranını artırmaktadır. Bu yasaya dayanarak ekonomik büyüme ile istihdam ve işsizlik arasındaki ilişkiyi inceleyen birçok araştırma yapılmıştır (Abdioğlu \& Albayrak, 2018; Bayrak, 2019; Çondur \& Bölükbaş, 2014; D'lppolito, 2011; Kabaklarlı \& Gür, 2011; Mazalliu \& Zojiani, 2015; Murat \& Y1lmaz Eser, 2013; Muratoğlu, 2011; Özdemir \& Yıldırım, 2015; Sam, 2016; Uras, 2016; Aslan \& Yamak, 2015). Yapılan bu araştırmaların bazılarında ekonomik büyümenin işsizlik oranını artırdığı, bazılarında düşürdüğü, bazılarında ise işsizlik ile ekonomik büyüme arasında bir ilişkinin olmadığı sonucuna ulaşılmıştır.

Günümüzde gelişmiş ülkelerde veya gelişmekte olan ülkelerde ekonomik büyüme gerçekleşmesine rağmen istihdamda artış gözlenmemekte, işsizlik oranı artmakta ya da gereğince düşürülememektedir. Bu durumun ortaya çıkması her ülke için aynı nedenlere bağlı değildir ve her ülkenin kendi etkenleri değişiklik göstermektedir. Bir ülkede ekonomik büyümeye rağmen işsizlik oranlarının yüksek olması tam olarak açıklanamamaktadır (Akkaya \& Gürbüz, 2006; Takım, 2015). Ekonomik büyümenin gerçekleşmesine rağmen, bu büyümenin istihdam yaratmaması ya da tam aksine işsizliği artırması literatürde istihdamsız büyüme olarak adlandırılmaktadır. Çaşkurlu (2014), istihdamsız büyümenin sebeplerini sözde ve özde nedenler olarak iki kısma ayırmıştır. Serbest piyasa yapılanmasının, aşırı emek arzı problemini ücret esneklikleri vasıtasıyla çözmesi, büyüme ve istihdam arasında geçici bir gecikmenin varlığı, küreselleşmenin rekabetçi piyasalar ortaya çıkarması ve sonuçta etkinlik arayışının istihdamda azalmaya neden olması, emeğin sınıfsal haklarına ilişkin hukuki düzenlemelerin sert ve emek faktöründeki vergi yükünün ağır olması ve teknolojik gelişmenin emeğin iş yükünü azaltması sözde nedenler olarak ifade edilmiştir. İç tasarruf yetersizliğinin sıcak para girişi ile karşlanması ve bu durumun GSMH'yi artırırken istihdam yaratmaması, istihdam ve büyüme arasında kendiliğinden işleyen bir ilişkinin olmaması etkenleri de özde etkenler olarak ifade edilmiştir. Literatürdeki çalışmalar ve ortaya atılan görüşler ekonomik büyümenin istihdam ve işsizlik üzerinde bir etkisi olduğu yönündedir ve bu nedenle bu çalışmada genç işsizliği etkileyen değişkenlerden biri olarak GSYH ele alınmıştır. 


\subsection{Yükseköğretim Harcamaları ve Genç İssizlik}

İşsizliğe ilişkin literatürde işsizlik ve genç işsizlik ile birlikte ele alınan değişkenlerden birisi de eğitimin düzeyidir. Eğitim düzeyinin, genç işsizlik üzerinde etkisinin ortaya konulduğu çalışmalar bulunmaktadır. Bireylerin eğitim düzeyi arttıkça istihdamda istikrar meydana gelmekte, eğitimli ve nitelikli bireylerin işsizlik oranı daha düşük seviyede olmaktadır (Weisberg \& Meltz, 1999). Bireylerin eğitim seviyesi arttıkça işsiz kalma riski düşmekte ve bunun yanında işsiz kalma süresi kısalmaktadır. Eğitim seviyesi yüksek olan bireyler iş arama durumunda daha etkin davranmaktadır. Bu durum onların işsiz kalma durumlarında daha kısa sürede iş bulmalarına olanak tanır ve işsizliğin bireysel maliyetleri düşüş gösterir (Saxton, 2000). Ancak eğitim seviyesi arttıkça genç işsizliğin tamamen ortadan kalkması söz konusu değildir. Çünkü, genç işsizlik sorunu tek başına eğitim düzeyi ya da eğitim harcamaları ile açıklanabilecek bir sorun değildir. Ancak bireylerin eğitim seviyesinin artması, stratejik eğitim harcamaları ile birlikte bireylerin niteliklerinin artması ve dolayısıyla daha kolay iş bulabilmeleri durumu söz konusudur. Bir ülkenin eğitim seviyesindeki artış, iş gücünün verimliliğini artırmakta, gelir dağılımının düzelmesine katkıda bulunmakta, bireylerin daha sağlıklı beslenmesini, sağlık düzeylerinin iyileşmesini ve nüfus artış hızının azalmasını sağlamaktadır (Tansel, 2009).

Literatürde eğitim ve işsizlik/genç işsizliği arasındaki ilişkiyi inceleyen çalışmalar bulunmaktadır. Bu çalışmaların bazılarında eğitim düzeyinin yükselmesinin genç işsizliği azalttığı (Brauns, Gangl, \& Scherer, 1999; Ekin, 1980; Hunady \& Pisar, 2016; Lavrinovicha, Lavrinenko, \& Teivans-Treinovskis, 2015; Özcan, Tepekule, \& Kayalıdere, 2016; Sayın, 2011) sonucuna ulaşılırken, bazı çalışmalarda ise eğitim düzeyinin işsizlik oranını azaltmadığı (Erdem \& Tugcu, 2012; Rajmohan \& Abeysekare, 2016) sonucuna ulaşılmıştır.

Eğitim düzeyi yükseldikçe genç işsizlik oranının azalması beklenen bir durumdur. Özellikle yükseköğretimin amaçlarından biri de işgücüne nitelik kazandırılması ve istihdamın kolaylaşmasıdır. Yükseköğretimin bireylere işgücü niteliği kazandırması; ülkenin eğitim politikası, ihtiyaç duyulan alanlarda eğitimin verilmesi, eğitimin kalitesi, eğitime yapılan harcamaların niteliğini artıracak şekilde tasarlanması gibi faktörlere bağlıdır. Dolayısıyla bu çalışmada genç işsizliği etkileyen faktörlerden biri olarak yükseköğretim harcamaları ele alınmıştır.

Ülkeler gelirleri oranında diğer eğitim seviyelerinde olduğu gibi yükseköğretim kurumlarına da bütçelerinde yer vermektedirler. Yükseköğretime yapılan harcamalar ülkeden ülkeye değişim göstermektedir. Bu oranı belirleyen birçok faktör bulunmaktadır. Ülkelerin gelirleri, yükseköğretim kurumlarının sayısı, ülkenin gelişmişlik düzeyleri, ülkenin nüfusu gibi etmenler yükseköğretime yapılan harcamaları etkileyebilmektedir. 
Şekil-3'te bazı ülkelerin gayri safi yurt içi hasıla içerisinde yükseköğretime ayırdıkları doğrudan harcamaların payları verilmiştir.

Şekil 3. Bazı Ülkelerin Yükseköğretim Kurumlarına Doğrudan Harcamalarının Gayri Safi Milli Hasıla İçindeki Oranı-2017 (\%)

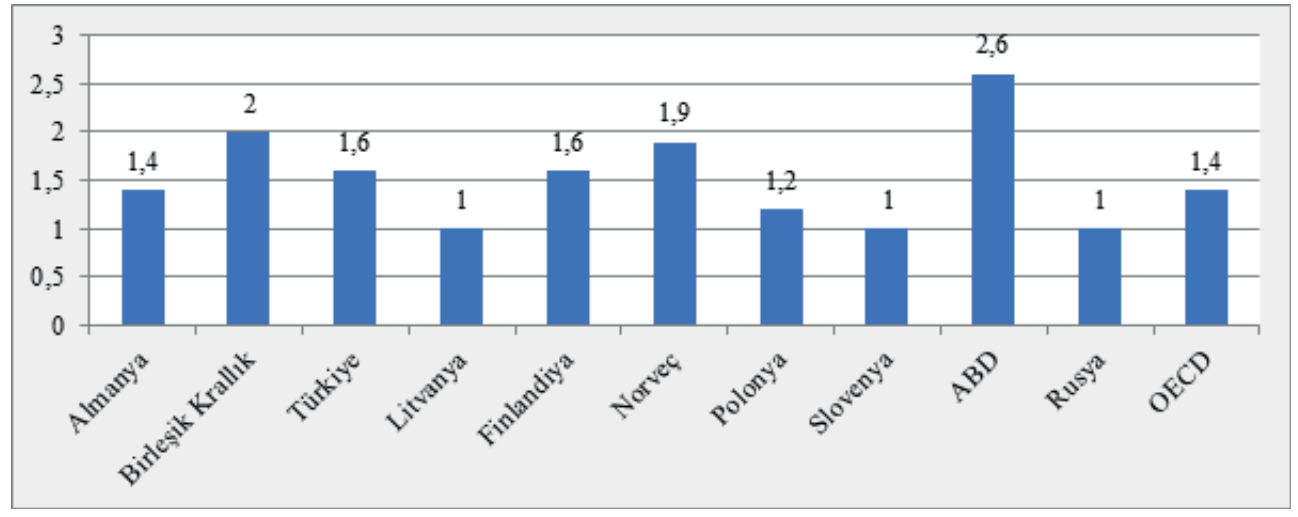

Kaynak:(OECD, 2020)

Yükseköğretim kurumlarına yapılan doğrudan harcama oranlarına bakıldığında OECD ortalamasının \%1,4 olduğu görülmektedir. Şekilde yer almayan diğer OECD ülkeleri de dahil edildiğinde en yüksek orana sahip ülke ABD'dir. En düşük orana sahip ülke ise Lüksemburg'dur (\%0,4) (OECD, 2019). ABD’nin yükseköğretime ayırdığı bütçe 2016 yılı itibarıyla 220 milyar 602 milyon dolardır (UNESCO, 2019). ABD’nin yükseköğretime ayırdığ 1 bütçenin yüksek olmasının sebepleri olaraknüfusunun fazla olması nedeniyle yükseköğretimde bulunan öğrenci sayısının ve yükseköğretim kurumları sayısının fazla olması ve milli gelirinin yüksek olması ifade edilebilir.2017 yılındaTürkiye'nin yükseköğretim kurumlarına ayırdığı doğrudan harcamaların oranı \%1,6'dır ve bu oran OECD ortalamasının üzerindedir.

Şekil 4. Gayri Safi Yurt İçi Hasılada Yükseköğretime Yapılan Harcamaların Oranı (\%)

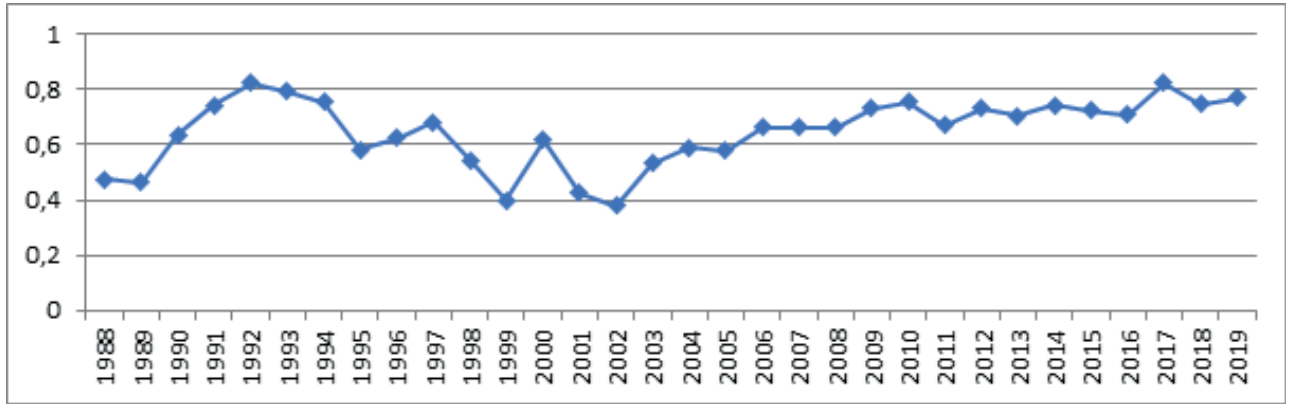

Kaynak:(MEB Strateji Geliştirme Başkanlığı, 2006; MEB, 2017; TÜiK, 2021'den elde edilen verilerden yararlanılarak araştırmacı tarafindan yapılan hesaplamalarla elde edilmiştir.) 
Türkiye'de yükseköğretim harcamaları cari olarak son 30 yılda sürekli olarak artış göstermiştir. Ancak bu artışın ülkenin geliri ile paralel olarak artış göstermesi önem taşımaktadır. Şekil-4'te Türkiye'de yükseköğretim harcamalarının gayri safi yurt içi hasıladaki oranındaki yıllara göre değişimi verilmiştir. Yıllar itibarıyla Türkiye'de yükseköğretime yapılan yatırımların gayri safi yurt içi hasıla içindeki oranı genel olarak bakıldığında artış göstermiştir. Ancak bu artış dalgalı bir grafik sergilemektedir. Türkiye'de en yüksek oranlara 2017 ve 1992 yıllarında, en düşük oranlara ise 2002 ve 1999 yıllarında ulaşılmıştır.

\subsection{Emek Verimliliği ve Genç İşsizlik}

Kısmi verimlilik çeşitlerinden biri olan emek verimliliği, verimliliğe ilişkin araştırmalarda sıklıkla kullanılmaktadır (Oyeranti, 2000). Emek verimliliği işletmelerin performanslarını ortaya koyan ve rekabet güçlerini belirten bir göstergedir. Emek verimliliğindeki yükselme, ülkenin ekonomik büyümesini doğrudan etkileyen faktörlerden birisidir. Nüfusun alım gücünü doğrudan etkileyen emek verimliliği genelde gayri safi milli hasılanın çalışan nüfusa bölünmesiyle hesaplanmaktadır. OECD’ye göre ise emek verimliliği; brüt çıktı endeksinin emek girdi endeksine bölünmesi ya da katma değer endeksinin emek girdi endeksine bölünmesi şeklinde hesaplanmaktadır (OECD, 2001).

Ekonomide istikrarın var olabilmesi için emek verimliliği ve ücretler arasında bir dengenin kurulması gerekmektedir. İşgücü verimliliği diğer faktörlerden ve ekonomik şartlardan etkilenmektedir (Oyeranti, 2003; Saraçoglu \& Suiçmez, 2006; Uzay, 2005). Bunların yanında emek verimliliği toplumsal kurallardan, geleneklerden, iklim ve coğrafi durumlardan, örgüt yapısından, üretim sistemlerinden etkilenmektedir (Uzay, 2005).Emek verimliliğini etkileyen etkenler sadece bunlarla sınırlı değildir. Çalışma zamanı, eğitimlerin yetersiz olması, kontrol mekanizmalarının olmaması, sağlık ve güvenlik etkenleri, çalışan bireylerin niteliksiz olması, yönetimin zayıf olması, denetimin zamanında yapılmaması gibi birçok faktör de emek verimliliği üzerinde etkiye sahiptir (Attar, Gupta, \& Desai, 2012).

Emek verimliliği üzerinde etkisi olduğu düşünülen faktörlerden birisi de genç işsizliktir. Verimlilik; ekonomik büyümenin, sosyal gelişmenin ve yüksek yaşam standartlarının en önemli itici gücünden birisidir (Prokopenko, 2001). Emek verimliliğindeki artış, işgücü talebinde kısa vadede azalmaya neden olabilir. Ancak uzun vadede verimliliğin artması istihdamın artmasına neden olabilir (Uzay, 2005). Emek verimliliğinin istihdam üzerindeki etkileri birçok araştırmada incelenmiştir (A ğazade \& Eştürk, 2019; Bayrak \& Tatli, 2018; Kabaklarlı \& Gür, 2011; Lentz \& Mortensen, 2004; Parisi, Marelli, \& Demodova, 2015; Tripier, 2002; Türkyılmaz \& Özer, 2008). Yapılan araştırmalarda istihdamdaki azalmanın emek verimliliğinde artışa neden olduğu (Ağazade \& Eştürk, 2019), emek verimliliği ile 
genç işsizliği arasındaki ilişkinin ülkelere göre farklılık gösterdiği (Parisi, Marelli, \& Demodova, 2015), emek verimliliğinin genç işsizlik üzerinde belirleyici olduğu (Bayrak \& Tatli, 2018), emek verimliliği ile işsizlik arasında kısa dönemde negatif bir ilişkinin olduğu (Tripier, 2002) sonuçlarına ulaşılmıştır. Bu nedenle bu araştırmada genç işsizliği etkileyen faktörlerden biri olarak emek verimliliği değişkeni de araştırmaya dahil edilmiştir.

\subsection{Brüt Sermaye Oluşumu ve Genç Isssizlik}

Çalışmada genç işsizlik üzerinde etkisinin araştırıldığ sermaye oluşumudur. Ülkenin fiziki sermaye stokunda meydana gelen değişimi resmetmekte olan bu gösterge, ekonomideki sermaye yatırımlarında yaşanan artış ile bağlantılı olarak teorik açıdan istihdamın da artmasını da sağlamaktadır.

Literatürde brüt sermaye oluşumu ve işsizlik/istihdam arasındaki ilişkiyi test eden birtakım çalışmalar bulunmaktadır. Imran ve Sial (2013), brüt sermaye oluşumu, ticari açıklık ve ücret seviyesinin Pakistan'da istihdam seviyesine olan etkisini analiz etmiştir. Analiz sonuçları brüt sermaye oluşumunun istihdam üzerinde pozitif ve anlamlı bir ilişkiye sahip olduğunu göstermektedir. Alrayes ve Abu Wadi (2018) Bahreyn’de işsizliği belirleyen faktörleri araştırdıkları çalışmalarında GSYH, enflasyon, kamu harcamaları, brüt sermaye oluşumu ile işsizlik arasındaki ilişkiyi test etmişlerdir. Çalışmanın çıktıları büyüme ve enflasyonun işsizliğe etki etmediğini, ancak brüt sermaye oluşumu ve kamu harcamalarının işsizlik üzerinde negatif etkisinin olduğu tespit edilmiştir. Pasara ve Garidzirai (2020) VAR modelini kullandığı çalışmalarında Güney Afrika için brüt sermaye oluşumu, istihdam ve ekonomik büyüme arasındaki nedensellik ilişkilerini incelemiştir. Analiz sonuçları brüt sermaye oluşumu ile ekonomik büyüme arasında uzun dönemde pozitif ilişkinin varlığını, brüt sermaye oluşumu ve işsizlik arasında ise uzun dönemli negatif bir ilişkinin varlığını göstermiştir. Sahoo ve Sahoo (2019), Hindistan' da iktisadi büyüme ve brüt sermaye oluşumu ile işsizlik arasında pozitif anlamlı bir ilişki olduğunu ortaya koymuştur.

\section{Veri Seti, Verilerin Analizi ve Yöntem}

Bu araştırmada kullanılan veri setine ilişkin bilgiler Tablo-1'de verilmiştir. Kullanılan veri seti 1988-2019 dönemini kapsayan yıllık gözlemlerden oluşturulmuştur. Çalışmanın bağımlı değişkeni genç işsizliktir ve İŞS notasyonu ile gösterilmektedir. İŞS ile uzun dönemli ilişkisi test edilecek bağımsız değişkenler ise yüksek öğretim harcamaları (YÖH), 2010 yılı sabit fiyatlarıyla (\$) kişi başına düşen reel GSYH $\left(\mathrm{GSYH}_{\mathrm{KB}}\right), 2010$ yılı sabit fiyatlarıyla (\$) brüt sermaye oluşumu (BSO) ve emek verimliliğidir (VER). Bağımsız değişkenlerin bağımlı değişken üzerinde beklenen etkisi YÖH için negatif, $\mathrm{GSYH}_{\mathrm{KB}}$ için negatif, BSO için negatif ve VER için pozitiftir. Çalışmada kullanılan tüm veriler doğal logaritmaları alınarak kullanılmıştır. 
Tablo 1: Veri Seri

\begin{tabular}{|c|c|c|c|}
\hline Değișken & Notasyon & Kaynak & Beklenen İlişki \\
\hline Genç İşsizlik & İŞS & TÜİK & \\
\hline Yüksek Öğretim Harcamaları & YÖH & $\begin{array}{l}\text { MEB, YÖK, Strateji ve Bütçe Başkanlığı, } \\
\text { Kalkınma Bakanlığı, Maliye Bakanlığı }\end{array}$ & negatif \\
\hline $\begin{array}{l}\text { Kişi Başına Düşen Reel } \\
\text { GSYH } \\
(2010 \text { sabit ABD \$) }\end{array}$ & $\mathrm{GSYH}_{\mathrm{KB}}$ & Dünya Bankası WDI & negatif \\
\hline $\begin{array}{l}\text { Brüt Sermaye Oluşumu } \\
(2010 \text { sabit ABD \$) }\end{array}$ & $\mathrm{BSO}$ & Dünya Bankası WDI & negatif \\
\hline Emek Verimliliği & VER & OECD & pozitif \\
\hline
\end{tabular}

\section{Yöntem}

Pesaran ve Shin (1999) ve Pesaran, Shin ve Smith (2001) tarafından geliştirilen ARDL eş bütünleşme sınır testi yaklaşımı, Engle ve Granger (1987) ve Johansen (1988) eş bütünleşme testlerinden farklı olarak serilerin düzeyde ya da birinci farkta durağan olmalarına bakılmaksızın seriler arasında uzun dönemli bir ilişki olup olmadığını test eder. Aynı zamanda bu yöntem küçük gözlem sayısına sahip verilerde bile tutarlı sonuçlar elde edilmesine (Baek \& Kim, 2013; Panopoulou \& Pittis, 2004) ve kısa ve uzun dönem sonuçlarının eş zamanlı tahmin edilmesine olanak sağlar.

ARDL eş bütünleşme sınır testi yaklaşımı standart F- ve t- istatistiklerine dayanır. Bu iki istatistiğin asimptotik dağılımları değişkenlerin durağanlık seviyeleri dikkate alınmaksızın hiçbir düzeyde ilişki olmadığı şeklindeki $\mathrm{H}_{0}$ hipotezi altında standart değildir. $\mathrm{Bu}$ yöntemde tüm değişkenlerin $\mathrm{I}(0)$ veya $\mathrm{I}(1)$ olduğu duruma göre değişen iki asimptotik kritik değer seti elde edilir. Elde edilen bu iki kritik değer seti değişkenlerin I(0), I(1) ya da karşılıklı eş bütünleşik olarak tüm olası sınıflandırmalarını kapsayan bir bant sağlar (Pesaran, Shin \& Smith, 2001). ARDL test prosedürü altında test edilen model aşağıdaki gibidir:

$$
\begin{aligned}
& \Delta \mathrm{I} S S_{t}=\propto_{0}+\sum_{i=1}^{p} \propto_{1} \Delta \mathrm{I} S S S_{t-i}+\sum_{i=0}^{p} \propto_{2} \Delta Y O ̈ H_{t-i}+\sum_{i=0}^{p} \propto_{3} \Delta G S Y H_{K B} t-i+\sum_{i=0}^{p} \propto_{4} \Delta B S O_{t-i}+ \\
& \sum_{i=0}^{p} \propto_{5} \Delta V E R_{t-i}+\lambda_{1} \dot{I} S S_{t-1}+\lambda_{2} Y O ̈ H_{t-1}+\lambda_{3} G S Y H_{K B}{ }_{t-1}+\lambda_{4} B S E_{t-1}+\lambda_{5} V E R_{t-1}+
\end{aligned}
$$

Yukarıdaki denklemde yer alan $\lambda_{1}$ 'den $\lambda_{6}{ }^{\prime}$ ya kadar olan ifadeler değişkenler arasındaki uzun dönem ilişkiyi temsil ediyorken $\propto_{1}{ }^{\prime}$ den $\propto_{6}{ }^{\prime}$ ya kadar olan ifadeler ise değişkenler arasındaki kısa dönemli ilişkiyi temsil etmektedir. Ek olarak $\alpha_{0}, \Delta$ ve $\varepsilon$ ifadeleri sırasıyla sabit, fark operatörü ve hata terimini temsil eder.

ARDL sınır testi yaklaşımı altında değişkenler arasındaki kısa ve uzun dönemli ilişkileri gösteren tüm test sonuçları birkaç aşama sonrasında elde edilir. İlk aşamada yukarıda 
gösterilen 1 numaralı denklem Akaike Bilgi Kriteri (AIC) ya da Schwarz Bilgi Kriteri (SIC) gibi uygun gecikme seçimi kriteri kullanılarak en küçük kareler yöntemi altında tahmin edilir. Ardından değişkenler arasındaki uzun dönem ilişkinin var olup olmadığını test etmek için F-testi uygulanır. Eş bütünleşmenin olmadığını ifade eden $H_{0}: \lambda_{0}=\lambda_{1}=\lambda_{2}=\lambda_{3}=\lambda_{4}=\lambda_{5}=\lambda_{6}=0$ hipotezi eş bütünleşme olduğunu ifade eden $H_{1}: \lambda_{0} \neq \lambda_{1} \neq \lambda_{2} \neq \lambda_{3} \neq \lambda_{4} \neq \lambda_{5} \neq \lambda_{6} \neq 0$ alternatif hipotezine karş1 test edilir. Elde edilen F-istatistik değeri Pesaran vd. (2001) tarafından hesaplanan üst ve alt kritik değerleri ile mukayese edilir. Eğer hesaplanan F- istatistik değeri üst kritik değerinden daha büyükse eş bütünleşmenin olmadığını ifade eden $H_{0}$ hipotezi reddedilir.

Değişkenler arasında uzun dönemli bir ilişkinin varlığg tespit edildikten sonra ikinci aşamaya geçilir. Bu aşamada genel bir hata düzeltme modeli (ECM) tahmin edilir. Yukarıda gösterilen 1 numaralı denklem ECM'nin tahmini için aşağıdaki şekilde yazılır:

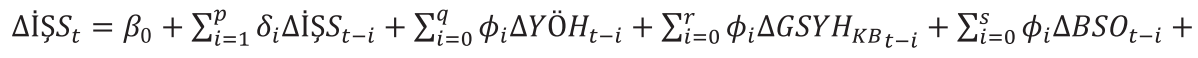

$$
\begin{aligned}
& \sum_{i=0}^{t} \phi_{i} \Delta V E R_{t-i}+\propto E C T_{t-1}+u_{t} \\
& E C T_{t}=\dot{\mathrm{I} S S S_{1}}-\propto_{1} Y \mathrm{OO} H_{t}-\propto_{2} G S Y H_{K B t}-\propto_{3} B S O_{t}-\propto_{4} V E R_{t}
\end{aligned}
$$

Yukarıda verilen 2 nolu denklemdeki $\triangle$ birinci fark operatörünü ifade eder. $u_{t}$ ise türdeş, bağımsız ve normal dağılıma sahip olduğuvarsayılan hata terimlerini göstermektedir. 3 numaralı denklemdeki $\alpha$ ifadesi hata düzeltme hızı parametresini, ECT ise hata düzeltme terimini ifade eder. Eğer gecikmeli hata düzeltme terimi olan negatif işaretli ve istatistiki olarak anlamlıysa, değişkenler ve katsayıları arasındaki uzun dönemli ilişkiyi doğrular ve bağımlı değişkendeki uzun dönemli dengeden sapmaların her zaman diliminde düzeltilme miktarını gösterir (Yusoff, 2010). 2 numaralı denklemden elde edilen eş bütünleşmenin varlığı sonucu tahmin edilen katsayıların stabil olduğu anlamını taşımaz. Bu sebeple son olarak CUSUM ve CUSUMSQ testleri yapılabilir.

\section{Model Tahmin Sonuçları}

Eş bütünleşme testlerinde ilk olarak kullanılan veri setine ait değişkenlerin durağanlıkları test edilmelidir. Bu amaçla öncelikle çalışmaya ait değişkenlerin durağanlıkları Genelleştirilmiş Dickey-Fuller (ADF) ve Phillips-Perron (PP) birim kök testleri ile sınanmıştır. Aşağıda Tablo-2'de değişkenlere ait ADF ve PP birim kök test sonuçları verilmiştir. Buna göre LNIŞS bağımlı değişkeninin her iki birim kök testi altında da birinci farkta \%1 anlamlılık seviyesinde durağan olduğu görülmektedir. LNGSYHKB ve LNBSO bağımsız değişkenleri hem ADF hem PP'ye göre birinci farkta ve \%1 anlamlılık seviyesinde durağanken LNYÖH ve LNVER bağımsız değişkenleri ise düzeyde \%1 anlamlılık seviyesinde durağandır. Dolayısıyla değişkenlerin durağanlıklarının sırasıyla I(1), I(0), I(1), 
I(1), I(0) olduğu görülmektedir. Söz konusu durağanlık seviyelerine göre bu modelin tahmininde ARDL uygulanması mümkündür.

Tablo 2: Birim Kök Test Sonuçları

\begin{tabular}{lcccc}
\hline & \multicolumn{2}{c}{ ADF } & PP \\
\hline Değişken & $\begin{array}{c}\text { t-istatistiği } \\
\text { (Düzey) }\end{array}$ & $\begin{array}{c}\text { t-istatistiği } \\
\text { (Birinci Fark) }\end{array}$ & $\begin{array}{c}\text { t-istatistiği } \\
\text { (Düzey) }\end{array}$ & $\begin{array}{c}\text { t-istatistiği } \\
\text { (Birinci Fark) }\end{array}$ \\
\hline LNIŞS & -2.043 & $-5.572 * * *$ & -1.964 & $-7.120 * * *$ \\
LNYÖH & $-7.683 * * *$ & - & $-7.683 * * *$ & - \\
LNGSYH & -2.489 & $-5.886 * * *$ & -2.514 & $-6.338^{* * *}$ \\
LNBSO & -2.669 & $-5.737 * * *$ & -2.669 & $-5.745 * * *$ \\
LNVER & $-5.829 * * *$ & - & $-6.003 * * *$ & - \\
\hline
\end{tabular}

Not: $* * *, * *$ ve $*$ sirasiyla $\% 1, \% 5$ ve $\% 10$ anlamlllık seviyelerini ifade eder.

ARDL modelinde optimum gecikme uzunluklarının belirlenmesi önemlidir. Bu nedenle AIC kullanılarak modelin değişkenlerine ait gecikme uzunlukları tespit edilmiştir. Buna

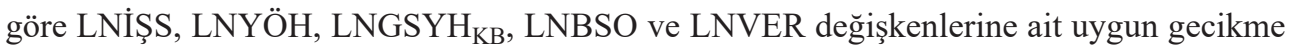
uzunlukları sırasıyla 3, 3, 0, 3, 0 olarak hesaplanmıştır.

Aşağıda verilen Tablo-3'te de görüleceği üzere F-testi 5.266 olarak hesaplanmıştır. Elde edilen bu değerin F(LNIŞS | LNYÖH, LNGSYH $\mathrm{KB}_{\mathrm{KB}}$, LNBSO, LNVER) için \%1 ve \%5 anlamlılık düzeylerinde üst kritik değerleri aştı̆̆ı görülmektedir. Elde edilen bu sonuç genç işsizliği, yüksek öğretim harcamaları, kişi başına düşen reel GSYH (2010 sabit ABD \$), brüt sermaye oluşumu ve emek verimliliği arasında uzun dönemli bir ilişkinin varlığını ima eder.

Tablo 3: Sınır Testi Sonuçları

\begin{tabular}{lcccccc}
\hline & & \multicolumn{3}{c}{ Kritik değerler \%1 } & \multicolumn{2}{c}{ Kritik değerler \%5 } \\
\hline & $\begin{array}{c}\text { Optimum gecikme } \\
\text { uzunluğu }\end{array}$ & F-istatistiği & I(0) & I(1) & I(0) & I(1) \\
\hline F (LNIŞS & & & & & & \\
$\begin{array}{l}\text { LNYÖH, } \\
\text { LNGSYH }\end{array}$ KB, & $(3,3,0,3,0)$ & 5.266 & 3.29 & 4.37 & 2.56 & \\
$\begin{array}{l}\text { LNBSO, } \\
\text { LNVER) }\end{array}$ & & & & & & \\
\hline
\end{tabular}

Not: I(0) alt sınır değerleri ve I(1) üst sınır değerleri Pesaran, Shin ve Smith (2001)'den alınmıştır.

Son olarak aşağıda Tablo 4'de elde edilen kısa ve uzun dönem ARDL eş bütünleşme test sonuçları verilmiştir. Elde edilen tahmin sonuçları ECT'nin \%73,6 olduğunu göstermektedir. $\mathrm{Bu}$ sonuca göre genç işsizlik bağımlı değişkeni bir şoka maruz kaldığında her bir zaman periyodunda uzun dönem denge durumuna \%73,6 oranında yaklaşacaktır. Başka bir şekilde ifade etmek gerekirse genç işsizlik oranı dış şok sonucunda dengeden saptıktan yaklaşık 1,36 yıl sonra tekrar dengeye gelecektir. Modelin uzun dönem katsayıları incelendiğinde tüm katsayıların \%1 veya \%5 seviyelerinde istatistiki olarak anlamlı olduğu görülmektedir. 
Uzun dönem katsayıları karşılaştırıldığında genç işsizlik üzerinde en yüksek etkiye sahip olan bağımsız değişkenin kişi başına düşen GSYH olduğu görülmektedir. Bu değişkeni sırasıyla brüt sermaye oluşumu, yüksek öğretim harcamaları ve emek verimliliği takip etmektedir.

Tablo 4: Kısa ve Uzun Dönem Analiz Sonuçları (3,3,0,3,0)

\begin{tabular}{|c|c|c|}
\hline Değişken & Kısa Dönem Katsayıları & t-İstatistiği \\
\hline$\Delta \dot{I}_{S} \mathrm{~S}_{\mathrm{t}-1}$ & -0.375 & $-1.781^{*}$ \\
\hline$\Delta \dot{I}_{S} \mathrm{~S}_{\mathrm{t}-2}$ & 0.676 & $2.643 * *$ \\
\hline$\Delta \mathrm{YÖH}_{\mathrm{t}}$ & -0.069 & -0.684 \\
\hline$\Delta \mathrm{YÖH}_{\mathrm{t}-1}$ & -0.190 & $-1.876^{*}$ \\
\hline$\Delta \mathrm{YÖH} \mathrm{t}_{-2}$ & -0.207 & $-2.210 * *$ \\
\hline$\Delta \mathrm{BSO}_{\mathrm{t}}$ & -1.031 & $-4.988 * * *$ \\
\hline$\Delta \mathrm{BSO}_{\mathrm{t}-1}$ & 0.141 & 0.996 \\
\hline$\Delta \mathrm{BSO}_{\mathrm{t}-2}$ & 0.519 & $3.860 * * *$ \\
\hline $\mathrm{C}$ & 15.45742 & $4.384 * * *$ \\
\hline \multirow[t]{2}{*}{$\mathrm{ECT}_{\mathrm{t}-1}$} & -0.736 & $-6.491 * * *$ \\
\hline & \multicolumn{2}{|c|}{ Uzun Dönem Katsayıları } \\
\hline LNYÖH & -0.058 & $-2.896 * * *$ \\
\hline LNGSYH $_{\mathrm{KB}}$ & 2.654 & $2.263 * *$ \\
\hline LNBSO & -1.183 & $-2.024 * *$ \\
\hline LNVER & 0.010 & $1.492 * * *$ \\
\hline $\mathrm{C}$ & 20.995 & $4.409 * * *$ \\
\hline Diagnostik Testler & \multicolumn{2}{|c|}{ p-değeri } \\
\hline$\chi^{2}$ (seri korelasyon) & \multicolumn{2}{|c|}{0.327} \\
\hline$\chi^{2}$ (heteroskedastisite) & \multicolumn{2}{|c|}{0.513} \\
\hline$\chi^{2}$ (normallik) & \multicolumn{2}{|c|}{0.718} \\
\hline CUSUM & \multicolumn{2}{|c|}{ Stabil } \\
\hline CUSUM of SQUARES & \multicolumn{2}{|c|}{ Stabil } \\
\hline
\end{tabular}

Not: ${ }^{* *}, * *$ ve * işaretleri sırasıyla $\% 1, \% 1$ ve $\% 10$ anlamlllık derecelerini göstermektedir.

Kısa dönem sonuçları incelendiğinde hesaplanan gecikme uzunluklarına bağlı olarak bağımlı değişken üzerinde etkili olan bağımsız değişkenlerin yalnızca LNYÖH ve LNBSO olduğu görülmektedir. Kısa dönem katsayılarının olasılık değerleri de yüksek öğretim harcamaları ve brüt sermaye oluşumunun birinci gecikmesi haricinde farklı düzeylerde istatistiki açıdan anlamlıdır. Kısa dönemde LNBSO'nun LNİŞS üzerindeki etkisinin LNYÖH'den genel olarak daha fazla olduğu görülmektedir.

Tahmin edilen modelin uzun dönem katsayılarına göre yüksek öğretim harcamalarında meydana gelen $\% 1$ birimlik artışın genç işsizliğini \%0,058 birim azalttığı görülmektedir. Elde edilen bu sonucun \%1 seviyesinde istatistiki açıdan anlamlı olduğu görülmektedir. 
Kamu harcamaları ile işsizlik arasındaki ilişki temelde iki yaklaşım üzerine kurulmuştur. Bunlardan birincisi klasik yaklaşımdır. Klasik yaklaşımda devletin kamu harcamaları yoluyla yaptığı girişimler, fiyatları etkilemekte ve kaynak dağılımının bozulmasına neden olmaktadır. Bu durumda ekonomik büyüme engellenmekte ve işsizlik artış göstermektedir. İkinci yaklaşım olan Keynesyen yaklaşımına göre, kamu kesiminin yaptığı faaliyetlerin mevcut talebi destekleyici, tam istihdamı sağlayıcı şekilde piyasayı etkilediğine, devletin kamu harcamaları ile işsizliği önleyici müdahalelerle aktif bir rol üstlenmesi gerektiğine vurgu yapmaktadır (Özuğurlu, 2005). Ayrıca Keynes'e göre cari, yatırım ve transfer harcamaları istihdam düzeyinin belirleyicisi durumundadır (Bocutoğlu, 2012; Ünsal, 2007). Yükseköğretim harcamaları dahil, eğitim hizmetleri için yapılan harcamalar, gelirin dağılımında etken olması, iktisadi büyüme, kalkınma ve ekonomik istikrarın sağlanması görevini üstlenmesi nedeniyle aynı zamanda bir yatırım harcamasıdır (Ortaç, 2003). Yatırım harcamaları milli geliri artırırken, işsizlik azalmaktadır. (Bulutoğlu, 1988, akt. Karaarslan, 2005).

Literatürde eğitim harcamaları ve işsizlik arasında yapılmış bazı çalışmalar bulunmaktadır. Çondur ve Cömertler Şimşir (2017) tarafından yapılan araştırmada GSYH içindeki eğitim harcamalarının oranı arttıkça genç işsizliğin arttığı sonucuna ulaşılmıştır. Onuoha ve Agbede (2019) tarafından yapılan araştırmada eğitim harcamalarının artmasının işsizlik oranını düşürdüğü sonucuna ulaşılmıştır. Horner, Zhang ve Furlong (2018) tarafından yapılan araştırmada yükseköğretime olan harcamaların artmasının genç işsizliği azaltıcı bir etki yaptığı sonucuna ulaşılmıştır. Singh ve Shastri (2020) tarafından Hindistan'da yapılan araştırmada eğitim harcamalarının işsizlik oranınına etkisi olmadığı sonucuna ulaşılmıştır.

Genç işsizliği üzerinde etkisi olan bir diğer değişken de kişi başına düşen GSYH'dir. Analiz sonuçlarına göre $\mathrm{GSYH}_{\mathrm{KB}}$ 'de meydana gelen \%1 birimlik artış genç işsizliğini $\%$ 2,654 birim artırmaktadır. Elde edilen sonuç \%5 seviyesinde istatistiki olarak anlamlıdır. $\mathrm{Bu}$ durum istihdamsız (istihdam yaratmayan) büyüme sorunu bağlamında açıklanabilir. Bir ülkede belirli bir zaman diliminde, iktisadi büyümenin istihdam yaratmaması veya istihdam artışını sağlamaması istihdamsız büyüme sorunu olarak adlandırılmaktadır (Konukman \& Aşkın, 2010). İşsizliğe neden olan etkenler farklılık gösterse de hem gelişmiş hem de gelişmekte olan ülkelerde en önemli sorun olarak geçerliğini korumaktadır. Günümüzde hem gelişmiş hem de gelişmekte olan birçok ülkede ekonomik büyüme sağlanmasına rağmen istihdamda artış görülmemektedir. İşsizlik oranı artmakta veya istenen düzeye düşmemektedir. Zaten istihdamsız büyüme veya yoksullaştıran büyüme tartışmasının temeli de tam olarak izah edilemeyen konulardan biridir (Akkaya \& Gürbüz, 2006). İstihdamsız büyüme, geniş anlamda büyümenin emek sınıfının şartlarını iyileştirmemesi veya olduğundan daha da kötü duruma götürmesi ve yoksulluğu azaltmaması veya artırması durumudur (Çaşkurlu, 2014). Bu araştırmanın sonuçlarından birisi de GSYH'de meydana 
gelen artışın genç işsizlikte belirli bir istihdam artışına neden olmamasıdır. Literatürde buna ilişkin çalışmalar da bulunmaktadır. Bayrak (2019) tarafından yapılan araştırmada işsizlik ile büyüme arasında tek yönlü, geniş tanımlı işsizlik ile büyüme arasında ise çift yönlü bir nedensellik ilişkisinin bulunduğu sonucuna ulaşılmıştır. Araştırma sonucuna göre ekonomik büyümenin istihdam yaratmadığı ve işsizliğe neden olduğu sonucuna ulaşılmıştır. Çondur ve Bölükbaş (2014) tarafından yapılan araştırmada ise GSYH'de meydana gelen değişimlerin genç işsizlik üzerinde doğrudan veya dolaylı olarak etkili olduğu sonucuna ulaşılmıştır. Muratoğlu (2011) tarafından yapılan araştırmada Türkiye' de ekonomik büyüme, işsizlik oluşumuna etki ederken, işsizliğin ekonomik büyümeye bir etkisinin olmadığı sonucuna ulaşılmıştır. Sam (2016) tarafından yapılan araştırmada ise GSYH'nin artmasının genç işsizliği artırdığı sonucuna ulaşılmıştır.

Test sonuçlarına göre brüt sermaye oluşumunun genç işsizliği üzerinde negatif ve $\% 5$ seviyesinde istatistiki olarak anlamlı bir etkisi bulunmaktadır. Brüt sermaye oluşumunda meydana gelecek \%1 birimlik artış genç işsizliğini \%1,183 birim düşürmektedir. Ekonomide var olan sermaye birikiminde yaşanacak artışın istihdam yaratması iktisadi anlamda beklenen bir durumdur. Elde edilen bu sonuç ilgili literatürle de uyumludur (Alrayes \& Abu Wadi, 2018; Imran \& Sial, 2013; Pasara \& Garidzirai, 2020; Sahoo \& Sahoo, 2019).

Son olarak emek verimliliği ile genç işsizliği arasında istatistiki olarak \%1 anlamlılık seviyesinde küçük ama pozitif bir ilişkinin varlığ 1 tespit edilmiştir. Uzun dönemde emek verimliliğinde meydana gelecek \%1 birimlik artışın genç işsizliğini \%0.01 birim artırdığ hesaplanmıştır. Literatürde genç işsizliği ve emek verimliliği arasındaki ilişkiyi test eden bazı çalışmalar bulunmaktadır. Bu çalışmaların bulguları ortak bir kanıyı ifade etmemektedir. Ağazade ve Eştürk (2019) tarafından yapılan araştırmada istihdamdaki azalmanın, emek verimliliğinde artışa neden olduğu sonucuna ulaşılmıştır. Parisi ve ark., (2015) tarafından yapılan araştırmada ise genç işsizliği ile emek verimliliği arasındaki ilişkinin ülke gruplarına göre farklılık gösterdiği sonucuna ulaşılmıştır. Euro-10 ülkelerinde bu ilişki olumlu ve anlamlı iken Euro-15 ülkelerinde, Rusya ve OECD ülkelerinde anlamlı olmadığı sonucuna ulaşılmıştır. Bayrak ve Tatli (2018) tarafından 31 OECD ülkesine ilişkin elde edilen veriler ile yapılan araştırmada ise emek verimliliğinin genç işsizlik üzerinde belirleyici olduğu sonucuna ulaşılmıştır. Tripier (2001) tarafından yapılan araştırmada emek verimliliği ile işsizlik arasında kısa dönemde negatif bir ilişkinin varlığı söz konusudur. Bayrak ve Tatli (2018) tarafından yapılan araştırmada genç işsizliği ile işgücü verimliliği arasında 0,01 anlamlılık düzeyinde anlamlı ve pozitif bir ilişki gözlenmiştir. İşgücü verimliliğindeki \%1'lik bir artış, genç işsizlik oranını yaklaşık \%0,71 artırmaktadır.

\section{Sonuç, Tartışma ve Öneriler}

İşsizlik ve genç işsizlik tüm dünyada olduğu gibi Türkiye'de de önemli sorunların başında gelmektedir. ILO’nun 2019 yılı verilerine göre dünyada genç işsizliğin ortalaması 
\%13,5’tir. Türkiye'de ise bu oran aynı yıl için \%25,2 olarak gerçekleşmiştir. Gerek gelişmiş ülkelerde gerek gelişmekte olan ülkelerde gerekse de gelişmemiş olan bazı ülkelerde genç işsizlik problemi mevcuttur. Ancak bazı gelişmiş ülkelerde genç işsizlik oranı diğer ülkelere göre daha düşük seviyededir.

Küresel olarak bir sorun haline gelmiş olan işsizliğin sonuçlarından en fazla etkilenen gençlerdir ve genç işsizliği etkileyen birçok faktör bulunmaktadır. 15-24 yaş arasındaki bireyleri kapsayan genç yaş grubunun eğitim görme oranının artması, yeni işlerin ortaya çıkması, deneyim eksikliği, genç bireylerin niteliklerinin işgücü piyasasının gereksinimlerini tam olarak karşılayamaması gibi durumlar bu nedenler arasında sayılabilir. Genç bireylerin eğitim görme oranlarının artması dışındaki sebeplerin bazı politikalarla çözüme kavuşturulması mümkün iken bu küresel sorunun çözülememiş olması genel işsizlikten en fazla genç kesimin etkilenmesine neden olmuştur (Erdayı, 2009).

$\mathrm{Bu}$ araştırmada genç işsizliği ile yükseköğretim harcamaları, kişi başı reel GSYH, brüt sermaye oluşumu ve emek verimliliği arasındaki ilişki ortaya konmaya çalışılmıştır. Araştırmanın sonucuna göre genç işsizliği ile yükseköğretim harcamaları, kişi başı reel GSYH, brüt sermaye oluşumu ve emek verimliliği arasında \%1 anlamlılık düzeyinde uzun dönemli bir ilişkinin varlığı tespit edilmiştir. Uzun dönem katsayıları karşılaştırıldığında genç işsizlik üzerinde en yüksek etkiye sahip olan bağımsız değişkenin kişi başına reel GSYH olduğu sonucuna ulaşılmıştır. Bu değişkeni sırasıyla brüt sermaye oluşumu, yükseköğretim harcamaları ve emek verimliliği takip etmektedir.

Çalışmanın analiz sonuçları Türkiye'de ekonomik büyümenin genç işgücü bakımından istihdam yaratmayan bir yapıda olduğunu göstermektedir. Bu sonucun altında, işverenlerin tecrübesiz, yeni mezun işçi çalıştırmaktan çeşitli sebeplerden ötürü kaçınıyor olması, genç işçilerin öz gelişimlerine yeterince önem vermiyor olmaları, emeklilik yaşının Türkiye'de yüksek olması gibi sebeplerin yattığı ifade edilebilir. Dolayısıyla genç istihdamı teşvik eden politikaların yürütülmesi gerekmektedir.

Bulgulara göre brüt sermaye oluşumundaki artışın genç işsizliğini azalttığı sonucuna varılmıştır. Ülkenin fiziki sermaye stokunda meydana gelen değişimi resmetmekte olan bu gösterge ekonomideki sermaye yatırımlarında yaşanan artış ile bağlantılı olarak teorik açıdan istihdamın artmasını da sağlamaktadır. Bu bağlamda ülkedeki emek başına düşen sermaye stokunu artırmaya yönelik sübvansiyon, vergi indirimi, bürokratik kolaylık vs. gibi sermaye oluşumunu teşvik edici politikalar uygulanmalıdır.

Araştırmanın diğer bir sonucuna göre emek verimliliği ile genç işsizliği arasında istatistiki olarak küçük ama pozitif bir ilişkinin varlığı tespit edilmiştir. Bu sonuç bazı araştırma sonuçlarıyla tutarlılık göstermektedir (Ağazade \& Eştürk, 2019; Bayrak \& Tatli, 
2018; Kabaklarlı ve ark., 2011; Lentz \& Mortensen, 2004; Parisi ve ark., 2015; Tripier, 2002). Emek verimliliği sermaye/emek oranının artırılması, bireylere kazandırılan mesleki eğitim, teknolojik yenilik ile doğrudan bağlantılıdır. Dolayısıyla yukarıda diğer faktörler için önerilen politikalar aynı zamanda emek verimliliğin artmasına da yardımcı olacak politikalardır.

Bu noktada yüksek öğretim harcamalarına ayrı bir parantez açmak yerinde olacaktır. Türkiye'de yükseköğretimde öğrenci başına yapılan harcamaların düşük olması, yükseköğretimden mezun bireylerin işsizlik oranlarının yüksek olması, yükseköğretime yapılan harcamaların genç işsizliği azaltması durumu birlikte değerlendirildiğinde Türkiye'de yükseköğretime yapılan harcamaların artması gerektiği ortadadır. Ancak bu artış bireylerin yükseköğretimden mezun olduktan sonra yeterli niteliğe kavuşmalarını sağlayacak şekilde olmalıdır. Türkiye'de 2020 yılı itibarıyla yükseköğretimde öğrenim gören öğrencilerin yarısından fazlası açık ve uzaktan eğitimde öğrenim görmektedir. Son yıllarda açık ve uzaktan eğitimin kalitesi tartışılmaktadır. Bu nedenle açık ve uzaktan eğitimin kalitesi değerlendirilmeli, açık ve uzaktan eğitimde akreditasyon sistemi geliştirilmeli, bu eğitim sistemini bireysel ve sosyal getirileri analiz edilmeli ve bireylerin istihdamına, ülkenin kalkınmasına yönelik etkileri incelenmelidir.

İşsizlik, sadece yükseköğretime yapılan harcamalarla ilişkilendirilebilecek bir olgu değildir. İşsizliğin temelinde birçok etken bulunmaktadır. Bu etkenler tümü ile birlikte değerlendirilmelidir. Bu değerlendirmelerde Türkiye'nin işsizlik ve istihdama, iş gücüne, eğitim politikalarına ilişkin özel durumları yok sayılmamalıdır. Türkiye'de yükseköğretime yapılan harcamaların genç işsizliğe ve eğitimin ekonomik büyümeye olumlu katkısı birlikte değerlendirildiğinde, bu alana yapılan stratejik harcamaların istihdamı artıracak, işsizliği azaltacak, ekonomik büyümeyi sağlayacak politikaların uygulamaya konulmasıyla bu sorunun azaltılabileceği değerlendirilmektedir.

Hakem Değerlendirmesi: Dış bağımsız.

Çıkar Çatışması: Yazarlar çıkar çatışması bildirmemiştir.

Yazar Katkıları: Çalışma Konsepti/Tasarım- M.M., Y.A.; Veri Toplama- M.M.; Veri Analizi/Yorumlama- F.Y.; Yazı Taslă̆ı- M.M., Y.A., F.Y.; İçeriğin Eleştirel İncelemesi- M.M., Y.A., F.Y.; Son Onay ve Sorumluluk- M.M., Y.A., F.Y.

Finansal Destek: Yazarlar bu çalışma için finansal destek almadığını beyan etmiştir.

Peer-review: Externally peer-reviewed.

Author Contributions: Conception/Design of Study- M.M., Y.A.; Data Acquisition- M.M.; Data Analysis/Interpretation- F.Y.; Drafting Manuscript- M.M., Y.A., F.Y.; Critical Revision of Manuscript- M.M., Y.A., F.Y.; Final Approval and Accountability- M.M., Y.A., F.Y. Conflict of Interest: The authors have no conflict of interest to declare.

Grant Support: The authors declared that this study has received no financial support. 


\section{Kaynakça/References}

Abdioğlu, Z., \& Albayrak, N. (2018). Genç işsizlik, eğitim ve ekonomik büyüme. Global Journal of Economics and Business Studies, 7(13), 8-20.

Akkaya, R., \& Gürbüz, R. (2006). Ekonomik büyümenin dinamikleri ve istihdam: Kaynaklar ve istihdam. B. Neyaptı (Ed.), Ekonomik büyüme ve işsizlik üzerine kitabı içinde (s. 185-196). Ankara: Türkiye Ekonomik Birliği Yayınları.

Alrayes, S. E., \& Abu Wadi, R. M. (2018). Determinants of unemployment in Bahrain. International Journal of Business and Social Science, 9(12), 64-74.

Ağazade, S., \& Eştürk, Ö. (2019). Türkiye tarım sektöründe emek verimliliği ve istihdam ilişkisinin incelenmesi. SGD-Sosyal Güvenlik Dergisi, 9(2), 237-254.

Aslan, B. Y., \& Yamak, A. (2015). Türkiye'de 2000-2013 döneminde büyümenin genç işsizliğe etkisinin vektör otoregresif model ile analizi. Siyaset Ekonomi ve Yönetim Araştırmaları Dergisi, 3.

Apaydın, F. (2018). Türkiye'de işsizliğin karakterirstiklerinin karşılaştırmalı analizi. Süleyman Demirel Üniversitesi Sosyal Bilimler Enstitüsü Dergisi (30), 159-200.

Attar, A. A., Gupta, A. K., \& Desai, D. B. (2012). A study of various factors affecting labour productivity and methods to improve it. IOSR Journal of Mechanical and Civil Engineering (IOSR-JMCE), 1(3), 11-14.

Baek, J., \& Kim, H. S. (2013). Is economic growth good or bad for the environment? Empirical evidence from Korea. Energy Economics, 36, 744-749.

Bayrak, R., \& Tatli, H. (2018). The determinants of youth unemployment: A panel data analysis of OECD countries. The European Journal of Comparative Economics, 15(2), 231-248.

Bayrak, S. (2019). Ekonomik büyüme, istihdam ve işsizlik ilişkisi: Geniş tanımlı işsizlik oranları ile Türkiye üzerine bir araştırma. Anemon Muş Alparslan Üniversitesi Sosyal Bilimler Dergisi, 7(6), 301-310.

Breen, R. (2005). Explaining cross-national variation in youth unemployment: Market and institutional factors. European Sociological Review, 21(2), 125-134.

Bocutoğlu, E. (2012). Karşılaştırmalı makro iktisat teoriler ve politikalar. Trabzon: Murathan Yayınevi.

Brauns, H., Gang1, M., \&Scherer, S. (1999). Education and unemployment: Patterns of labour market entry in France, the United Kingdom and West Germany. Mannheimer Zentrum für Europäische Sozialforschung. Erişim adresi: http://www.mzes.uni-mannheim.de/publications/wp/wp-6.pdf

Bulutoğlu, K. (1988). Kamu Ekonomisine Giriş. İstanbul: Filiz Kitapevi.

Calderon, E. R. (2004). Getting young people into work: A challenge and an opportunity. Policy Proposal for Decent Work. Geneva: ILO.

Çaşkurlu, E. (2014). İstihdamsız büyüme (istihdamsız iyileşme) sorununa karşı kamusal politikalar ve önemi: Türkiye açısından bir değerlendirme. Amme İdaresi Dergisi, 47(2), 43-76.

Çetinkaya, E. (2010). Genç işsizliğin teorik açıklamaları. Sosyal Siyaset Konferansları Dergisi, (58), 45-57.

Çondur, F., \& Bölükbaş, M. (2014). Türkiye`de işgücü piyasası ve genç işsizlik-büyüme ilişkisi üzerine bir inceleme. Amme İdaresi Dergisi, 47(2), 77-93.

Çondur, F., \& Cömertler Şimşir, N. (2017). Türkiye'de eğitim harcamaları, ekonomik büyüme ve genç işsizlik ilişkilerinin analizi. Uluslararası Bilimsel Araştırmalar Dergisi, 2(6), 44-59.

Devlet Planlama teşkilatı. (2000). Uzun vadeli strateji planı ve sekizinci beş yıllık kalkınma planı 2001-2005. Ankara: Devlet Planlama Teşkilatı. Erişim adresi: http://www.bilgitoplumu.gov.tr/wp-content/uploads/2015/01/ Sekizinci_Kalkinma_Plani.pdf

D'Ippolito, N. (2011). Youth unemployment the cases of Denmark and Italy. Department of Economics Copenhagen Business School. Erişim adresi: https://research-api.cbs.dk/ws/portalfiles/portal/58451921/nadia_dippolito. $p d f$ 
Ekin, N. (1980). Gençlerin işsizlik sorunu. İstanbul: Fakülteler Matbaası. Erişim adresi: https://dergipark.org.tr/tr/ download/article-file/101180

Engle, R. F., \& Granger, C. W. (1987). Co-integration and error correction: Representation, estimation, and testing. Econometrica, 55(2), 251-276.

Erdayı, U. (2009). Dünyada genç işsizliği sorununun çözümüne yönelik ulusal politikalar ve Türkiye. Çallşma ve Toplum, 3(22), 133-162.

Erdem, E. \& Tugcu, C. T. (2012). Higher education and unemployment: a cointegration and causality analysis of the case of Turkey. European Journal of Education, 47(2), 299-309.

Güler, B. (2011). İşsizlik ve yarattığı psiko-sosyal sorunların öğrenilmiş çaresizlik bağlamında incelenmesi. İstanbul Üniversitesi İktisat Fakültesi Mecmuası, 55(1), 373-394.

Gümüş, E., \& Şişman, M. (2014). Eğitim ekonomisi ve planlaması. Ankara: Pegem Akademi.

Gürsel, S. (2005, 2 Ocak). İşsizliği yenmek için (3). Vatan Gazetesi

Hesapçıoğlu, M. (1984). Türkiye’de insangücü ve eğitim planlaması. Ankara: A.Ü. Eğitim Bilimleri Fakültesi Yayınları.

Horner, S., Zhang, A., \& Furlong, M. (2018). The Impact of higher education on unemployment. Erişim adresi: https://smartech.gatech.edu/bitstream/handle/1853/60545/ econ_3161_research_paper. pdf? sequence $=1 \&$ isAllowed $=\mathrm{y}$

Hunady, J., \& Pisar, P. (2016). Higher education and regional unemployment: Is there any relation between them. Erişim adresi: https://www.researchgate.net/profile/Jan-Hunady/publication/310605337_HIGHER_ EDUCATION_AND_REGIONAL_UNEMPLOYMENT_IS_THERE_ANY_RELATION_BETWEEN_ THEM/links/58331e7708aef19cb81c9367/HIGHER-EDUCATION-AND-REGIONAL-UNEMPLOYMENTIS-THERE-ANY-RELATION-BETWEEN-THEM.pdf

Imran, M., Sial, M. H., \& Zaman, B. (2013). Employment, trade openness and capital formation: Time series evidence from Pakistan. Journal of Global and Scientific Issues, 1(4), 37-42.

International Labour Organization. (2019). Unemployment. Erişim adresi: https://www.ilo.org/shinyapps/ bulkexplorer20/?lang=envesegment=indicatorveid=UNE_TUNE_SEX_AGE_NB_A

International Labour Organization. (2020). Global employment trends for youth 2020:Technology and the future of jobs. Erişim adresi: https://www.ilo.org/wcmsp5/groups/public/---dgreports/---dcomm/publ/documents/ publication/wcms_737648.pdf

İzgi, B. B. (2012). Genç işsizliği ve eğitim ile olan ilişkisi. Elektronik Sosyal Bilimler Dergisi, 11(41), 295-310.

Johansen, S. (1988). Statistical analysis of cointegration vectors. Journal of Economic Dynamics And Control, 12(23), 231-254

Kabaklarlı E., Er, P. H., \& Buluş, A. (2011). Economic determinants of youth unemployment problem: co-integration analysis, International Conference on Applied Economics-ICOAE, 267-272.

Kabaklarl1, E., \& Gür, M. (2011). Türkiye'de genç işsizlik sorunu ve ekonomik belirleyicilerinin uzun dönem eşbütünleşme analizi, 1-16, Erişim adresi: https://acikerisim.aku.edu.tr/xmlui/bitstream/handle/11630/7371/ Turkiye_de_Genc_Issizlik_Sorunu_ve_Ekono.pdf?sequence $=1 \&$ isAllowed $=\mathrm{y}$

Karaarslan, E. (2005). Kamu kesimi eğitim harcamalarının analizi. Maliye Dergisi, (149), 36-73.

Kavak, Y. (1997). Eğitim, istihdam ve işsizlik ilişkileri. Hacettepe Üniversitesi Eğitim Fakültesi Dergisi, (13), 2126.

Kelleci, S. Ü. ve Türk, Z. (2016). Genç işsizliğin incelenmesi: OECD ülkeleri ve Türkiye karşılaştırması. $H A K-I S ̧$ Uluslararası Emek ve Toplum Dergisi, 5 (13), 1-16. 
Konukman, A. T. \& Aşkın, R. (2010). Krizin Türkiye ekonomisine yansımaları ve geleceğe ilişkin düşünceler. Ekonomik Yaklaşım, 21 (75), 77-132.

Lentz R., \& Mortensen D. T. (2004). Productivity growth and worker reallocation: Theory and evidence. Centre for Applied Microeconometrics,1-31, Erişim adresi: https://citeseerx.ist.psu.edu/viewdoc/ download?doi=10.1.1.957.7888\&rep=rep1\&type $=$ pdf

Lavrinovicha, I., Lavrinenko, O., \& Teivans-Treinovskis, J. (2015). Influence of education on unemployment rate and incomes of residents. Procedia-Social and Behavioral Sciences, 174, 3824-3831.

Mazalliu, M., \& Zogjani, J. (2015). The effect of education and economic growth in the labour market in transition economies-case study for SEE countries, Academic Journal of Business Admistration, Law and Social Sciences, 1(2), 156-167.

Milli Eğitim Bakanlığı. (2017). Milli Eğitim İstatistikleri, Örgün Ĕgitim, 2016-2017. Ankara: Milli Eğitim Bakanlığı. Erişim adresi: http://sgb.meb.gov.tr/www/milli-egitim-istatistikleri-orgun-egitim-20162017/ icerik/270

MEB Strateji Geliştirme Başkanlığı. (2006). 2007 Bütçesine İlişkin Rapor. Ankara: Devlet Kitapları Müdürlüğü Basım Evi. Erişim adresi: http://sgb.meb.gov.tr>2007_yili_butce_rapo ru

Mroz, T. A., \& Savage, T. H. (2006). The long-term effects of youth unemployment. Journal of Human Resources, 41(2), 259-293.

Murat, S., \& Şahin, L. (2011). Nedenleri ve sonuçları bakımından gençler arasında yaygınlaşan işsizlik. Sosyoloji Konferanslarl, (44), 1-48.

Murat, S., \& Yılmaz Eser, B. (2013). Türkiye'de ekonomik büyüme ve istihdam ilişkisi: İstihdam yaratmayan büyüme olgusunun geçerliliği. Hak İs Uluslararası Emek ve Toplum Dergisi, 2(3), 92-123.

Muratoğlu, Y. (2011). Ekonomik büyüme ve işsizlik arasındaki asimetrik ilişki ve Türkiye'de Okun Yasasının sinanmasl (Yüksek lisans tezi). Hitit Üniversitesi Sosyal Bilimler Enstitüsü, Çorum.

OECD. (2001). Measuring productivity. Erişim adresi: http://www.oecd.org/sdd/productivity-stats/2352458.pdf

OECD. (2020). Education at a Glance 2020. Erişim adresi: https://www.oecd.org/education/education-at-a-glance/

O'higgins, N. (1997). The challenge of youth unemployment. International Social Security Review, 50(4), 63-93.

Ortaç, F. R. (2003). Cumhuriyetimizin 80. yılında eğitim harcamaları. Gazi Üniversitesi İktisadi ve İdari Bilimler Fakültesi Dergisi, 5(2), 239-247.

Onuoha, F. C., \& Agbede, M. (2019). Impact of disagregated public expenditure on unemployment rate of selected African countries: A panel dynamic analysis. Journal of Economics, Management and Trade, 24(5), 1-14. https://doi.org/10.9734/jemt/2019/v24i530175

Oyeranti, G. A. (2000). Concept and measurement of productivity by. Erişim adresi: http://www.cenbank.org/out/ Publications/occasionalpapers/rd/2000/Abe-00-

Özcan, P. M., Tepekule, U., \& Kayalıdere, G. (2016). Eğitim kalitesinin genç işsizliği ile ilişkisi: PISA test sonuçları üzerinden bir değerlendirme. Aydın İktisat Fakültesi Dergisi, 1(2), 89-113.

Özdemir, B. K. \& Yıldırım, S. (2015). Türkiye'de ekonomik büyüme ve istihdam arasındaki nedensellik ilişkisinin analizi: Özçıkarımlı dalgacık yaklaşımı. Dumlupınar Üniversitesi Sosyal Bilimler Dergisi, 38, 97-116.

Özer, U., \& Topal, M. H. (2017). Genç işsizliği, suç, göç, intihar, ve boşanma düzeyleri ile ilişkili midir? Türkiye'den ampirik bir kanıt. Kırklareli Üniversitesi İktisadi ve İdari Bilimler Fakültesi Dergisi, 6(5), 50-63.

Özuğurlu, Y. (2005). Kamu harcamalarının bölüşüm ilişkileri üzerine etkisi: Türkiye açısından bir değerlendirme. Ekonomik Yaklaşım Dergisi, 16(55), 59-88.

Pasara, M. T., \& Garidzirai, R. (2020). Causality effects among gross capital formation, unemployment and economic growth in South Africa. Economies, 8(2), 1-12. https://doi.org/10.3390/economies8020026 
Panopoulou, E., \& Pittis, N. (2004). A comparison of autoregressive distributed lag and dynamic OLS cointegration estimators in the case of a serially correlated cointegration error. The Econometrics Journal, 7(2), 585-617.

Pesaran, M. H., \& Shin, Y. (1999). An autoregressive distributed lag modelling approach to cointegration analysis. Cambridge Working Papers in Economics. Erişim Adresi: https://ideas.repec.org/p/cam/camdae/9514.html

Pesaran, M. H., Shin, Y., \& Smith, R. J. (2001). Bounds testing approaches to the analysis of level relationships. Journal of Applied Econometrics, 16(3), 289-326.

Prokopenko J. (2001), Verimlilik yönetimi: Uygulamalı el kitabı (O. Baykal vd., Çev.). Ankara: MPM Yayınları.

Raffe D. (1986) Change and continuity in the youth labour market: A critical review of structural explanations of youth unemployment. Allen S., Waton A., Purcell K., Wood S. (Ed.) The experience of unemployment. explorations in sociology içinde (s. 45-60). Palgrave Macmillan, London.

Rajmohan, R., \& Abeysekera, N. (2016). Impact of the quality of university education on labour market in Sri Lanka. International Journal of Business and Management Invention, 5(9), 71-76.

Sahoo, M., \& Sahoo, J. (2019). The relationship between unemployment and some macro economic variables: Empirical evidence from India. Theoretical and Applied Economics, 16, 115-28.

Sam, S. O. (2016). Modelling economic determinants of youth unemployment in Kenya. Journal of Emerging Trends in Economics and Management Sciences, 7(1), 31-38.

Parisi M. L., Marelli E., \& Demidova, O. (2015). Labor productivity of young and adult temporary workers and youth unemployment: A cross-country analysis, TEALM, Naples, 1-37. Erişim adresi: https://www.siecon.org/ sites/siecon.org/files/oldfiles/uploads/ 2014/10/Parisi-Marelli-Demidova-169.pdf

Pirler, B. (2007). Genç işsizliği sorunu ve çözmeye yönelik politikalar. TiSK Akademi, Özel Sayı-1, 147-156.

Sapancalı, F. (2005). Avrupa Birliği’nde sosyal dışlanma sorunu ve mücadele yöntemleri. Çalışma ve Toplum, 3(6), 51-105.

Saraçoğlu, B., \& Suiçmez, H. (2006). Türkiye imalat sanayinde verimlilik, teknolojik gelişme, yapısal özellikler ve 2001 krizi sonrası reel değişimler (1980-2005). Verimlilik Raporu- 2006, Ankara: Milli Prodüktivite Merkezi.

Sayın, F. (2011). Türkiye'de 1988-2010 döneminde eğitim ve büyümenin genç işsizliğine etkisinin analizi. Dokuz Eylül Üniversitesi Sosyal Bilimler Enstitüsü Dergisi, 13(4), 33-53.

Saxton, J. (2000). Investment in education: Private and public returns. Erişim adresi: http://busecon.wvu.edu/ phd_economics/pdf/16-05.pdf

Seçer, B. (2006). Uluslararası boyutuyla genç işsizliği ve gençlere yönelik istihdam politikaları. TiSK Akademi, (2), 78-97.

Singh, D., \& Shastri, S. (2020). Public expenditure on education, educational attainment and unemployment nexus in India: An empirical investigation. International Journal of Social Economics, 47(5), 663-674.

Takım, A. (2015). Türkiye'de ekonomik büyüme ile işsizlik arasındaki ilişki: Granger nedensellik testi. Dumlupınar Üniversitesi Sosyal Bilimler Dergisi, (27).

Tansel, A. (1999). Türkiye ve seçilmiş ülkelerde eğitimin getirisi. ODTÜ Gelişme Dergisi, 26 (3-4), 454-472.

Tripier, F. (2002). The dynamic correlation between growth and unemployment. Economics Bulletin, 5(4), 1-9.

Türkiye İstatistik Kurumu. (2021). Istihdam, işsizlik ve ücret. Erişim adresi: https://data.tuik.gov.tr/Kategori/Get Kategori?p=istihdam-issizlik-ve-ucret-108\&dil=1

Türkyılmaz, S., \& Özer, M. (2008). A time series analysis of Turkish unemployment. MIBES Transactions, 2(1), 175-89.

UNESCO. (2019). National monitoring. Erişim adresi: http://data.uis.unesco.org/Index.asp x?queryid =183

Uzay, N. (2005). Verimlilik ve büyüme. Ankara: Nobel Yayın Dağıtım. 
Uras, Ö. (2016). Türkiye ekonomisindeki istihdamsız büyümenin ekonometrik analizi, Ekonometri ve İstatistik Dergisi, (24), 94-111.

Ünsal, E. (2007). Makro iktisat. Ankara: İmaj Yayınevi.

Yılmaz, T., Fidan, F., \& Karataş, V. (2004). İşsizliğin sosyo-psikolojik sonuçları: Sosyo-demografik özeliklere göre bireylerin tutumları (bir alan araştırması). Sosyal Siyaset Konferansları Dergisi, (48), 163-183.

Yusoff, M. B. (2010). The effects of real exchange rate on trade balance and domestic output: A case of Malaysia. The International Trade Journal, 24(2), 209-226.

Wachter, M. L. (1980). The dimensions and complexities of the youth unemployment problem. Youth Employment and Public Policy, 33-63.

Weisberg, J., \& Meltz, N. (1999). Education and unemployment in Israel, 1976-1994: Reducing the anomaly. Relations industrielles/Industrial Relations, 54(4), 673-693. 
